\title{
Reconciliation in the Templeless Age: The Servant as Sanctuary in Isa 53
}

\author{
Paba Nidhani De Andrado (St Louis University)
}

\begin{abstract}
Isaiah 53 has been at the crossroads of Jewish-Christian polemical debate about the identity of the unnamed figure. This article emphasises that it is not the identity but the function of the Servant which is pivotal. This study examines relevant terms, imagery, and allusions in Isa 53 to determine intertextual links to cultic texts. It investigates the Servant's association with the triple roles of priest, sacrifice and offerer/sinner while also considering his expiatory function. The study frames this cultic portrayal of the Servant as a response to the "templeless age." The destruction of the temple in 587 B.C.E resulted in a dilemma for the deportees who sought to reconcile with their deity in a foreign land. The traumatic loss of the temple resulted in creative ideas of how to access God in the absence of a sanctuary. Isaiah 53 addresses the cultic void by shifting the site and means of expiatory atonement from a physical place (the temple) to a person (the Servant).
\end{abstract}

KEYWORDS: Isaiah 53, Servant, Fourth Servant Song, Temple, Sacrifice, Expiation, Biblical cult, Reconciliation, Atonement

\section{A INTRODUCTION}

The identity of the Suffering Servant in Isa 53 has preoccupied exegetes, Jewish and Christian, modern and ancient alike, arousing polemical debate. ${ }^{1}$ In contrast

* Submitted: 30/03/2021; peer-reviewed: 31/05/2021; accepted: 16/11/2021. Paba N. De Andredo, "Reconciliation in the Templeless Age: The Servant's Function as Sanctuary in Isa 53," Old Testament Essays 34 no. 3 (2021): 915 - 935. DOI: https://doi.org/10.17159/2312-3621/2021/v34n3a15

I would like to thank the following for their academic support and contributions to my research: Selamawit Fsha, Dominic Laible, Prof Daniel Smith and Prof Lori Baron.

1 For Christian interpretations, see W. H. Bellinger Jr. and William R. Farmer, eds., Jesus and the Suffering Servant: Isaiah 53 and Christian Origins (Harrisburg: Trinity Press, 1998). Recent scholarship has moved from questions of identity. For example, see Jeremy Schipper, Disability and Isaiah's Suffering Servant (Oxford University Press, 2011). For rabbinic and medieval Jewish interpretations, see the (still valid) compilation by S.R. Driver and A.D. Neubauer, eds., The Fifty-third Chapter of Isaiah: According to the Jewish Interpreters (Oxford: James Parker and Co., 1877, repr. 2005). A useful discussion on Jewish interpretations may be found in Joel E. Rembaum, "The Development of a Jewish Exegetical Tradition Regarding Isaiah 53," HTR 75 (1982): 289-311. 
to Christian tradition which read the passage as a prophecy of Jesus, Jewish exegetes tended to view the Servant as a collective figure of the Jewish people suffering in exile. ${ }^{2}$ This essay maintains that the decisive question is not who the Servant is but how the Servant functions in Isa 53. In other words, what purpose does the Servant (עבד) in Isa 53 serve? ${ }^{3}$

In pursuing this inquiry, we shall examine the distinctive cultic depiction of the Servant in this passage. The Servant's role can be best understood in terms of the expiatory function of the temple, which held significance as the central holy place for ancient Jews. ${ }^{4}$ The Jerusalem sanctuary was considered the site "where the deity abided among a chosen people, from which divine presence and protection were mediated." 5 Temple ritual included sacrifice, with priests offering animals/food items brought by the people. While "humans can drive God out of the sanctuary by polluting it with their moral and ritual sins," the regular and proper performance of sacrifice maintains the divine presence in the sanctuary. ${ }^{6}$ Although expiation of sins is not the sole function of ritual sacrifice, the sanctuary was the key locus of atonement where expiatory sacrifices and the Azazel (עזאזל) atonement ritual (Lev 16) were carried out. Following the temple's destruction in 587 B.C.E. and with exile viewed as a punishment for sin (cf. Lev 18:25; Deut 28:63-65), the deportees faced the dilemma of effecting reconciliation without a sanctuary. The traumatic loss of the temple resulted in creative ideas of "how to access God in a foreign land." "Isaiah 53 represents a

2 Rabbi Shlomo Yitzchaki (Rashi) comments that Israel suffered in order to make atonement for other nations. See Rashi's Commentary on Isa 53:3-6.

3 There are multiple references to עבד in (Deutero) Isaiah. The Servant is identified with Israel/Jacob $(41: 8 ; 44: 1-2,21 ; 45: 4 ; 49: 3)$, a prophetic voice $(44: 26)$, a person tasked with bringing back Israel/Jacob (49:5-6) and justice to the nations (42:1). Bernhard Duhm's 1892 commentary, Das Buch Jesaia, designates four "servant songs" (Isa 42:1-4; 49:1-6; 50:4-9 and 52:13-53:12) though recent scholars have questioned this redactional isolation. Refer Cullen Story, "Another Look at the Fourth Servant Song of Second Isaiah," Horizons in Biblical Theology (2009): 100-110.

4 For a nuanced discussion on the problematics of a central space, see Hayim Lapin and Marjorie Lehman, "Introduction to the Theme: The Jerusalem Temple in History, Memory, and Ritual," AJS Review 43 (2019): 265-269 (266), "With each construction of the Jerusalem Temple we expose different issues and theological perspectives that do more to convince us that the Jews of antiquity were struggling with the burden of one central holy space, inasmuch as they wished to embrace and identify with it as well."

5 Jill Middlemas, The Templeless Age: An Introduction to the History, Literature, and Theology of the "Exile" (Louisville: Westminster John Knox Press, 2007), 142.

6 J. Milgrom, Leviticus 1-16: A New Translation with Introduction and Commentary (AB 3; New York: Doubleday, 1991), 43.

7 Middlemas, Templeless, 26. One notion was to anticipate the restoration of the Temple, like Ezekiel's blueprint for a Temple (Ezek 40-46). Another approach was to give emphasis to prayer, as in Jeremiah's lesson to the exiles that God will hear their prayer wherever they reside (Jer 29: 12-14). 
novel approach as the Servant serves the purpose of filling the cultic void during the "templeless" age. ${ }^{8} \mathrm{We}$ shall explore the thesis that in the absence of a physical place, the site and modus of atonement shifts to the person of the Servant in whom the roles of priest, offerer and offering intersect, as in the former sanctuary.

\section{B CRITICAL DISCUSSION}

A useful starting point is the date of composition and context of Isa 53. While precise dating remains uncertain, traditionally, scholars locate the composition of Deutero-Isaiah (chs. 40-55) in Babylonia, during the exilic period. ${ }^{9}$ Juliana Claassens comments,

Deutero-Isaiah grew out of a situation where people experienced a profound sense of powerlessness generated by the trauma caused by exile... the rejection and abuse depicted in the fourth servant song (Isa. 52:13-53:12) may suggest something of the suffering and disappointment the prophet experienced. ${ }^{10}$

Admittedly, the authorship of Isa 53 remains disputed, nevertheless, dating its composition to the templeless age is a reasonable claim. ${ }^{11}$ My presupposition is that Isa 53 was written prior to the restoration of the (second) temple, in response to the ordeal of exile. ${ }^{12}$

In investigating the Servant's function in Isa 53, this study finds pertinent the debate on the cultic connotations of this pericope. Recent scholarship has

8 Middlemas, Templeless Age, 137, defines the term "templeless" as the "period following the downfall of Judah [which] is best spoken of as the templeless age... 'templeless' clarifies a time frame - that epic period between the two temples [587 515 B.C.E]."

9 R. Albertz, Israel in Exile: The History and Literature of the Sixth Century B.C.E. (trans. D. Green; Atlanta: Studies in Biblical Literature, 2003), 401; B.D. Ehrman, The Bible: A Historical and Literary Introduction (New York: Oxford, 2014), 150: "[Second Isaiah] is normally dated some years after the exile began and certainly before it came to a decisive end with the decree of Cyrus that allowed the exiles to return to the land to rebuild the Temple."

10 L.J.M. Claassens, "Interrupting God-language: Re-thinking the Image of God as Liberator in Isaiah 42," in Exile and Suffering: A Selection of Papers Read at the 50th Anniversary Meeting of the Old Testament Society of South Africa OTWSA/OTSSA, Pretoria, August 2007 (ed. B. Becking and D. Human; Leiden: Brill, 2009), 68-69.

11 Middlemas, Templeless, 93, locates Deutero-Isaiah [inclusive of the Servant Songs] among literature composed toward "the second half of the templeless age."

12 Refer D. G. Garber Jr., "Trauma Theory and Biblical Studies," Currents in Biblical Research 14 (2015): 24 -44. Trauma studies has highlighted the impact of "the collapse of the religious center of the Jerusalem Temple, the eradication of political autonomy, and the erosion of the social fabric that occurred during the Babylonian destruction"; Garber Jr., "Trauma Theory," 30-31. 
examined the sacrificial associations of the Servant, either positing or denying the connections of Isa 53 to cultic ritual. ${ }^{13}$ For example, Blenkinsopp observes analogous links between the Servant's role and the ritual of reparation offering in Leviticus, while Schipper argues against such a notion, suggesting that Isa 53 describes the Servant "not as an ideal sacrificial animal but as an animal physically unfit for sacrifice." 14 Some commentators have observed linguistic and conceptual resonances between Isa 53 and priestly texts. Ha observes, "cultic allusions are found in the technical terms and phrases/clauses which are either terminologically or ideologically connected with the Hebrew cultic institution, especially in the book of Leviticus." 15 Other scholars deny the influence of sacrificial material on Isa 53, claiming that there is not enough of the same terminology in the Isaiah text or the relevant passages from Leviticus to make a compelling connection. ${ }^{16}$ Moreover, exegetes have disputed whether specific terminology employed in Isa 53 originated in cultic or secular contexts. For instance, Janowski claims that the word אשם in Isa 53:10 has a non-cultic origin (cf. 1 Sam 6), while Milgrom holds a contradictory view "1 Sam 6 does not concern a civil crime and cannot be used as a basis for claiming a civil origin for the asham."17

\section{METHODOLOGICAL APPROACH}

Given critical disputes, this study finds it useful to examine relevant vocabulary in Isa 53 to determine which (if any) of its terms manifest a cultic connection. Methodologically, this study will draw on intertextuality, a concept initially articulated by Julia Kristeva and advanced by Roland Barthes. ${ }^{18}$ While Kristeva considers it problematic that "[intertextuality] has often been understood in the

13 For studies on the cultic associations of Isa 53, see J. Blenkinsopp, "The Sacrificial Life and Death of the Servant (Isaiah 52:13-53:12)," VT 66 (2016): 1-14; J. Schipper, "Interpreting the Lamb Imagery in Isaiah 53," JBL 132 (2013): 315-325; Bernd Janowski and Peter Stuhlmacher, eds., The Suffering Servant: Isaiah 53 in Jewish and Christian Sources (Grand Rapids: Wm B. Eerdmans, 2004); Kyesang Ha, "Cultic Allusions in the Suffering Servant Poem (Isaiah 52:13-53:12)" (Ph.D. diss., Andrews University, 2009); http://digitalcommons.andrews.edu/dissertations.

14 Blenkinsopp, "Sacrificial Life," 1; Schipper, "Lamb Imagery," 325.

15 Ha, "Cultic Allusions," 44.

16 Refer Schipper, "Lamb Imagery," 320.

17 B. Janowski, "He Bore Our Sins: Isaiah 53 and the Drama of Taking Another's Place," in The Suffering Servant: Isaiah 53 in Jewish and Christian Sources (ed. B. Janowski and P. Stuhlmacher; Grand Rapids: Eerdmans, 2004), 68-69. Contrastingly, see J. Milgrom, Cult and Conscience: The Asham and the Priestly Doctrine of Repentance (Studies in Judaism in Late Antiquity 18; Leiden: Brill, 1976), 14 n. 47.

18 Roland Barthes, "The Theory of the Text" in Untying the Text: A Post Structuralist Reader (ed. Robert Young; Boston: Routledge and Kegan Paul, 1981), 31-47. 
banal sense of "study of sources""19 but that the widespread and effective use of the term by biblical scholars cannot be disregarded. As Moyise remarks, "the word 'intertextuality' has taken on a life of its own... it is best used as an 'umbrella' term for the complex interactions that exist between 'texts' (in the broadest sense)." ${ }^{20}$ Biblical scholars differ in their definitions and approaches, which has led to suggestions for a more careful distinction between terms and methods. ${ }^{21}$

This study considers intertextuality as the best approach to determining connections between Isa 53 and relevant biblical texts, particularly, cultic writings like Leviticus. Admittedly, close correspondences between texts may result from direct dependence, coincidence or the use of a common tradition. In determining intertextuality, we will consider the following features: lexical resonances of words and phrases, thematic parallels, shared contexts or conceptual frameworks, and the innovative use of a biblical notion or text to create new meanings or transform previous understandings. Such an endeavour may seem subjective: "What one scholar thinks is enough to make a connection between two texts, another scholar may not."22 Nevertheless, pursuing substantive resonances enables us to explore possible sacrificial associations. We will pay particular attention to the range and extent of linguistic and conceptual parallels to cultic texts in Isa 53. An extensive and frequent pattern of correspondences can serve to confirm that rather than being coincidental occurrences, Isa 53 reflects a cultic context in its choice of vocabulary.

\section{CULTIC ELEMENTS IN ISA 53}

In order to demonstrate intertextuality, this section will examine Isa 53 for its (apparent) use of sacrificial terminology, imagery and motifs related to the Servant's portrayal. The following eight items of vocabulary from the pericope

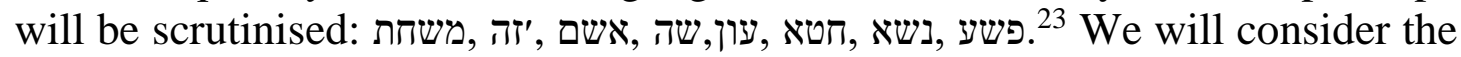
meaning of each term and its occurrence in biblical texts to determine any cultic resonances.

One key word is משחת in the MT version (Isa 52:14) which has been translated as marring or disfigurement and connected to the root שחת (to corrupt/

19 Julia Kristeva, "The Kristeva Reader (ed. Toril Moi; New York: Columbia UP, 1986), 111.

20 Steve Moyise, "Intertextuality and Biblical Studies: A Review," Verbum et Ecclesia 23 (2002): 429-430.

21 Russell L. Meek, "Intertextuality, Inner-biblical Exegesis, and Inner-biblical Allusion: The Ethics of a Methodology," Biblica 95 (2014): 280-291. See also Richard Hays, Echoes of Scripture in the Letters of Paul (New Haven: Yale University, 1989).

22 Schipper, "Lamb Imagery," 322.

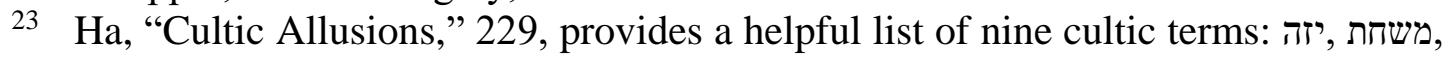

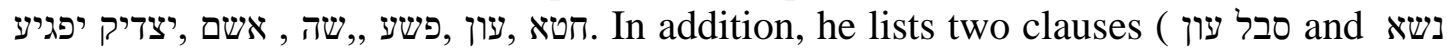
דיקט). 
ruin/ spoil). ${ }^{24}$ The phrase appears in 52:14 so marred from a man was his appearance." The cultic association of משתת משתח מs suggested by its usage in Mal 1:14, albeit with reference to blemished animals which are unacceptable as sacrificial victims. Another pertinent understanding of משחת is as a noun deriving from the root משח (anoint). ${ }^{25}$ The Isa 53 version in 1QIsa ${ }^{a}$ contains the form משחתי ("I have anointed") which strengthens the case. This notion of "anointing" links the Servant to cultic priests who are consecrated with anointing oil (i.e. Lev 8:12; 16:32). Plausibly, משחת manifests cultic connotations, including the priesthood of the Servant.

Another word that merits scrutiny is יזה in the phrase: כן יזה גוים רבים shall he [sprinkle] many nations" (Isa 52:15). The term יזה derives from the hiphil form of the root נזה and appears in both MT and 1QIsa ${ }^{a}$ versions. It is a common verb used to describe the priestly act of sprinkling blood for atonement (e.g, Lev $4: 6,17 ; 5: 9)$. Sprinkling has an effect of purging impurities and is integral to the Day of Atonement rites (Lev 16:14, 15) as well as purification offerings for the high priest and community (Lev 4:6, 17). Some scholars have disputed the cultic meaning of יזה. Childs states, "the verb $n z h$ (hiphil) never designates the person or thing sprinkled, but the blood [fluid] being applied." 26 Hermisson too maintains, "the object upon which or toward which the fluid is sprinkled [should be]... always preceded by one of the prepositions לפני or,", which is not the case in Isa 52:15. ${ }^{27}$ Both scholars raise valid technical points. Nevertheless, since Isa 53 is a poetic text, we may consider that it lacks grammatical precision such as a direct object marker (את) or a preposition. Given that נזה is well attested in ritual contexts, the term is best regarded as a cultic term in accordance with the primary lexical meaning of the hiphil form (sprinkling). A priest can "only sprinkle or make atonement when he is first anointed as priest (cf. Lev 16:32)... the servant sprinkles because he is anointed." ${ }^{28}$ Clearly, the word יזה in Isa 53 reinforces the idea of the Servant as a priest-like figure.

24 See Peter J. Gentry, "The Atonement in Isaiah's Fourth Servant Song (Isaiah 52:1353:12)," The Southern Baptist Journal of Theology 11 (2007): 28.

25 Gentry, "Atonement," 28: "If the Masoretic Text is respected in both consonantal text and vocalization, there are two possibilities: (1) a noun with preformative mem derived from the root שחת ("to ruin"), or (2) a feminine noun derived from the root ("to anoint"). The meaning of the noun, then, is either 'ruining' or 'anointing' depending upon whether option (1) or (2) is adopted... The noun משחה is well attested in biblical texts whereas a noun משחת ("destruction") is otherwise unknown in the Hebrew Scriptures."

26 B.S. Childs, Isaiah (Louisville: Westminster John Knox, 2001), 412.

27 Hans-Jürgen Hermisson, "The Fourth Servant Song in the Context of Isaiah," in The Suffering Servant: Isaiah 53 in Jewish and Christian Sources (ed. B. Janowski and P. Stuhlmacher; Grand Rapids: Wm B. Eerdmans, 2004), 29 n.42.

28 Gentry, "Atonement," 29. 
יראה , אשם is also a significant term, appearing in the statement "If you make his soul a reparation offering/he shall see seed, he will prolong [his] days" (Isa 53:10). The word אשם זשם occurs mostly in cultic writings, including in Leviticus $(5: 6,7,19,25 ; 7: 5 ; 14: 21$; 19:21), Numbers $(5: 7 ; 6: 12)$ and Ezekiel $(40: 39 ; 42: 13 ; 44: 29)$. According to Milgrom, the cultic texts reveal four usages of the root אשם: the nouns "reparation" and "reparation offering" and the verbs "incur liability [to someone]" and "feel guilt." 29 The term or reparation offering is an expiatory sacrifice which is required for the following situations: unintentional trespass of the Lord's holy things (Lev 5:14-16); suspected unintentional trespass of the Lord's holy things (Lev 5:17-19); intentional oath violation and advertent defrauding of another's property (Lev 5:20-26). In all cases, the erasure of the offence and, therefore, the guilt required a ritual process involving the sacrifice of an animal. ${ }^{30}$ Although feelings of guilt are integral to this process, the basic feature of the sacrifice is its function as a means of reparation. ${ }^{31}$ It is the only type of sacrifice commutable to currency (the temple shekel). ${ }^{32}$ The priest assesses the damage incurred with an additional fee of one-fifth and the purchase of a sacrificial animal (Lev 5:15-16). From a cultic standpoint, Isa 53:10 conveys the idea of the Servant as an אשם sacrifice effecting expiation, in reparation for the offences of others.

Some scholars reject a cultic interpretation of אשם in Isa 53.33 Their objections largely hinge on Janowski's argument that אשם originally came from secular contexts (cf. Gen 26:10; 1 Sam 6:3-4, 8, 17) concerning reparation for guilt-incurring encroachments and from there "the term made its way, after several intermediate stages and after the composition of Isaiah 53 into the priestly sacrificial torah (Lev 4-5, 7, passim)."34 Janowski is correct in stating that possesses non-cultic meanings ${ }^{35}$ but the notion that the term originated in a civil context is disputed (see n. 17). Moreover, the assertion that אשם entered the priestly laws "after the composition of Isaiah 53" is well countered by Blenkinsopp who states:

$[\mathrm{O}]$ ne objection which may be fairly quickly set aside is the contention that the cultic laws catalogued in Leviticus and Numbers are later than Isaiah $53 \ldots$ in their essential features, they go back long

\footnotetext{
29 Milgrom, Leviticus 1-16, 344.

30 Blenkinsopp, "Sacrificial Life," 5.

31 G.A. Anderson, "Sacrifice and Sacrificial Offering," ABD 5 (ed. D.N. Freedman et al.; New York: Doubleday, 1992), 880.

32 Milgrom, Leviticus 1-16, 327.

33 Janowski, "He Bore," 67-69; Childs, Isaiah, 418; Fredrik Hägglund, Isaiah 53 in the Light of Homecoming after Exile (Tübingen: Mohr Siebeck, 2008), 43.

34 Janowski, "He Bore," 68-69.

35 See Milgrom, Leviticus 1-16, 339-341.
} 
before any date that could be reasonably assigned to their final redaction. ${ }^{36}$

Evidence indicates that אשם was an established cultic term, in currency much prior to the composition of Isa 53 (e.g., 2 Kgs 12:17). Milgrom observes that אשם belongs to the pre-exilic priestly lexicon of repentance, later displaced אשם in the cultic laws of Leviticus and Numbers also validates locating the reference in Isa 53 within its primary ritual context. This cultic meaning of serves to affirm the link between the Servant and a sacrificial offering.

Isaiah 53 further associates the Servant with animal sacrifice in the verse "כשה לטבח יובל/Like a sheep led to slaughter" (53:7). According to the BDB, the term שה designates one of a flock, a sheep (or a goat), which was commonly used in ritual sacrifices. ${ }^{38}$ The word שה is employed for sacrificial offerings in multiple texts (e.g., Lev 5:7; 12:8; Num 15:11; Deut 18:3; Isa 43:23; 66:3; Ezek 45:15) including for burnt offerings, well-being offerings, purification offerings and as Passover sacrifices. Blenkinsopp observes, "the lamb is one of the animals most acceptable for sacrifice... The bringing of the victim to the place of slaughter, with the verb יובל (Hophal), is, moreover, commonly used in accounts of bringing sacrifices and offerings of different kinds to a deity or potentate." "39 It seems reasonable then to attribute the phrase "a sheep [or lamb] led to slaughter" (Isa 53:7) to a cultic context.

However, Schipper objects that "it is not clear that the lamb is slaughtered as a ritual sacrifice." 40 He points out that the word for "slaughter" (טבח) in Isa 53:7 is not used in the context of ritual sacrifice (i.e. Leviticus and Numbers) but rather טבח refers to the work of a cook or butcher killing for food or it serves metaphorically for the wartime slaughtering of humans as a divine punishment. ${ }^{41}$ Schipper's claim has merit since cultic laws do not employ טבח but instead in P, שחט is the technical term for ritual slaughter. ${ }^{42}$ Nonetheless, one finds examples of טבח in non-ritual texts where its usage evokes a cultic context, as in the phrase: For the LORD has a sacrifice in Bozrah, and a great slaughter in the land of Edom" (Isa 34:6). The parallelism between the word "slaughter" [טבח] and "sacrifice" [זבח] and the preceding imagery of slaughtered lambs and goats with the fat of the kidneys of rams

36 Blenkinsopp, "Sacrificial Life," 9.

37 Milgrom, Leviticus 1-16, 5, 377, writes: "P devised its terminology at a time when $\check{s} w b$ had not become the standard idiom for repentance. However, under the influence of the prophets, especially Jeremiah and Ezekiel, the root $\check{s} w b$ overwhelmed all of its competitors, including 'šm."

38 BDB, 961.

39 Blenkinsopp, "Sacrificial Life," 7.

40 Schipper, "Lamb Imagery," 316.

41 Ibid., 321.

42 See Milgrom, Leviticus 1-16, 154. 
suggests ritual sacrifice. ${ }^{43}$ Further, 1 Sam 9:24 employs טבח with cultic connotations when the cook or slaughterer (הטבח) gives Saul the שוק or thigh, which indicates a priestly portion ${ }^{44}$ as well as the עליה, (which likely refers to the fatty tail) since both pieces of meat evoke a ritual context. ${ }^{45}$ It appears then that in non-priestly texts, טבח did not exclusively convey secular slaughter but could imply a context of sacrifice, as is likely the case in Isa 53:7.

Additionally, Schipper observes that the image of a slaughtered lamb in Isa 53:7 does not come from a ritual text but from Jer 11:19 ("But I was like a gentle lamb led to the slaughter [טבח]") and Ps 44:23 (“...we are being killed all day long, and accounted as sheep for the slaughter [טבח" He denies that the verses associate "idioms involving animals led to the slaughter with the ritual sacrifices described in Leviticus." 46 Nevertheless, as previously discussed, the image of a sheep led to slaughter is congruent with a cultic context, given that the sheep was a common sacrificial animal. ${ }^{47}$ It is likely that Isa 53:7 drew on a tradition in which righteous sufferers who were unjustly treated are compared to cultic images of innocuous sheep led to slaughter, as in Jer 11:19 and Ps 44:23. By associating the Servant with a sacrificial animal, Isa 53:7 suggests that the Servant's suffering is unjust, comparable to an innocent lamb led to slaughter.

Another cultic animal evoked in Isa 53 is the Azazel (עזאזל) goat, commonly known as the scapegoat in the annual Day of Atonement ritual presented in Lev 16. The goat is one of a pair brought before the high priest who, after the drawing of lots, selects one goat for slaughter as a purification offering (16: 8-9). Upon the other goat, the high priest lays his hands and confesses all the wrongdoings of the Israelites, after which the animal is sent off to the wilderness (16:21-22). Although Isa 53 does not directly refer to the "scapegoat," a lexical link between the servant and the scapegoat lies in the root גזר (cut). In the scapegoat ritual, just as the sins of the people are carried away into the wilderness, "literally, 'a cut-off land' (ארץ), גזזרה (so the Servant is 'cut

43 Schipper, "Lamb Imagery," 321 n.19. He calls Isa 34:6 "the one exception that proves the rule." One could counterargue that the verse disproves that such a rule exists. 44 J.S. Greer, "The 'Priestly Portion' in the Hebrew Bible: Its Ancient Near Eastern Context and Its Implications for the Composition of P," JBL 138 (2019): 263-284, notes: "Two sections in Exod 29 and Lev 7:28-36 and numerous references elsewhere (e.g., Lev 8:25-26, 9:20-21, 10:14-15, Num 18:18) grant the priests the 'hindlimb' שוק" (265)."

45 Refer BDB 46 for the meaning of עליה connecting it with אליה (fatty tail) found in ritual texts such as Lev 3:9; 7:3; 8:25.

46 Schipper, "Lamb Imagery," 321.

47 Milgrom, Leviticus 1-16, 163: "the sheep is the most frequent burnt offering in the cult [which] figures in the daily, Sabbath, and festival sacrifices, sacrifices (Lev 9:3; 23:12, 18; Exod 29:38-41; Num 28-29; Ezek 46:13), in the chieftains' gifts for the inauguration ceremony of the altar, for impure persons $(12: 6 ; 14: 10)$, and for the desanctification of the temporary Nazirite (Num 6:14)." 
off from the land of the living' [Isa 53:8]... it is entirely probable that this rite, with atonement by means of sacrificial blood (Lev 16:21-22), was in the mind of the author of Isaiah 53."48

Moreover, the Servant and scapegoat are thematically connected in that both bear others' misdeeds. Lev 16 states: ונשא השעיר עליו את כל עונתם / "the goat

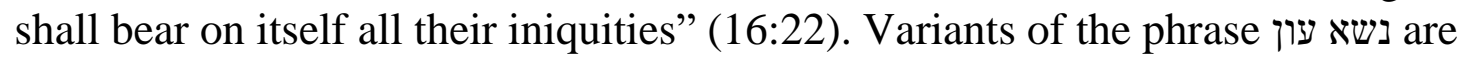
found in Isa 53 in relation to the Servant's bearing others' sin as in: והוא רבים נשא 'An 'A

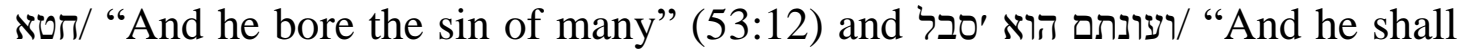
bear their iniquities" (53:11). While the expiatory significance of these verses will be examined later, for now, we note their resonances. Zimmerli observes that despite the variant terms ( נשא חטא עון סבל Used for the concept of bearing iniquity in Isa 53, it remains in line with the use of נשא עון within the priestly tradition (including the scapegoat in Lev 16:22, and in Lev 10:17). ${ }^{49}$ However, נשא Spieckermann questions Zimmerli's claims, observing that the exact phrase עון does not occur in Isa 53. ${ }^{50}$ Janowski too observes that in Isa 53, "Israel's guilt is not 'gotten rid of' by a scapegoat in some remote area; it is rather endured, borne by the Servant."51 Both Spieckermann and Janowski consider it problematic that neither the precise words nor exact context of the scapegoat ritual is reproduced in Isa 53.

Does the absence of exact replication negate the possibility of a close connection between the two passages of Lev 16 and Isa 53? As stated, intertextuality is helpful in determining a textual relationship based on lexical similarities such as shared vocabulary and conceptual parallels. Nevertheless, such correspondences need not be exact: "often the author of the alluding text will invert the order... or break up phrases and rearrange their constitutive elements." ${ }^{\prime 2}$ One text may illuminate or transform the understanding of a prior text without being identical to it, albeit they are linked by verbal and semantic resonances. On this basis, the scapegoat in Lev 16 and the Servant in Isa 53 manifest intertextuality both by the language and concept of iniquity bearing. The terms נשא חטא עון belong to cultic phraseology and it seems that the clauses נשא חטא in Isa 53) specifically are employed to underscore the cultic

48 Blenkinsopp, "Sacrificial Life," 8.

49 W. Zimmerli, “Zur Vorgeschichte von Jes. 53," Congress Volume, Rome, 1968 (ed.

G. W. Anderson et al; VTSup 17; Leiden: 1969), 238-240.

50 Hermann Spieckermann, "The Conception and Prehistory of the Idea of Vicarious Suffering in the Old Testament," in The Suffering Servant: Isaiah 53 in Jewish and Christian Sources (ed. B. Janowski and P. Stuhlmacher; Grand Rapids: Wm B. Eerdmans, 2004), 3.

51 Janowski, "He Bore," 68.

52 G. Miller, "Intertextuality in Old Testament Research," Currents in Biblical Research 9 (2010): 295. 
intentions of the Servant. ${ }^{53}$ The nexus between the scapegoat and the figure in Isa 53 could be deemed as stemming from a cultic background.

Sacrificial terminology in Isa 53 also includes three terms for wrongdoing namely פשע משון (sin, iniquity and transgression, respectively). In the Hebrew Bible, the words may occur together (e.g., Lev 16:21) as well as separately, each possessing distinct nuances. The word applications as pointed out in the BDB — sin against human beings, sin against God, guilt of sin and punishment for $\sin .^{54}$ The term חטא appears in cultic and secular contexts, including once in Isa (53:12): והוא חטא רבים נשא "And he bore the sin of many." Since the linking of חשט with the verb נשא occurs exclusively in cultic writings such as in Lev 24:15 and 22: 9, this usage of חטא in Isa 53:12 may be designated a cultic term, influenced by priestly tradition. Furthermore, the phrase "bore the sins of many" serves to highlight the Servant's affinity to sinners, as he bears sins on their behalf.

The word עון is another term deployed thrice in Isa $53(53: 5,6,11)$. It means iniquity, guilt or punishment for iniquity. ${ }^{55}$ In the cultic system, "עוך is removed by the perpetrators' purification offerings throughout the year (Lev 5,1. $6)$, borne by priests $(10,17)$, and then purged from the camp on the Day of Atonement $(16,21) .{ }^{\prime 56}$ Although the use of עון is not limited to cultic contexts, the three references in Isaiah thematically fit a sacrificial setting. Isaiah 53:5 states that "[he was] crushed for our iniquities," while verse 6 declares, And the Lord has laid on him the iniquity of us all" and verse 11 states ועת ערון / "he will bear their iniquities." These verses emphasise the Servant's vicarious role on behalf of sinners, enduring the consequences of their iniquities.

The term פשע/ transgressions also appears in Isa 53, twice as a noun (53:5, 8) and twice in its verbal form (53:12). Milgrom observes that "the noun peša" means 'rebellion' and its verb, pāša', 'rebel'" and that it originated in the political sphere but "by extension, it is transferred to the divine realm, where it denotes Israel's rebellion against its God (e.g., Isa 1:2)... it is the term that characterizes the worst possible sin: open and wanton defiance of the Lord." 57 The phrase in Isa 53:8, מפשע עמי נגע למו /for the transgressions of my people, he was stricken," accentuates that the Servant suffers because of others' wrongdoings. Alternatively, Schipper raises "a possible implication of interpreting the word 'stricken' in the sense of 'diseased' or 'plagued,' [with] Isa 53:3 and 8 provid[ing] additional evidence that . . the passage does not describe

53 Ha, "Cultic Allusions," 244.

54 BDB, 307.

55 Ibid., 730.

56 Ha "Cultic Allusions," 169.

57 Milgrom, Leviticus 1-16, 1034. 
the Servant as fit for participation in certain ritual activities." ${ }^{58}$ However, the Servant's strickenness is a consequence of his bearing sin rather than an inherent "diseased" condition rendering him unfit for sacrifice. Further, the statements, "he was pierced for our sins"/ והוא מחלל מפשענו (53,5) and "surely he has borne our diseases"/ reinforce that the Servant's association with disease should be understood figuratively as referring to sins, as confirmed by the LXX which uses the word $\alpha \mu \alpha \rho \tau$ ías to translate the MT's חלי (53:4).

The above arguments contradict the view that "the repeated use of expressions like 'sickness,' 'marred,' and 'despised' in Isaiah 53 creates an overall context that compares the Servant to an animal unfit for use in certain ritual activities." ${ }^{59}$ Unlike a sacrificial animal which is disqualified because it is blemished to begin with, the Servant is not portrayed as ritually unfit but as ideal because he is "righteous" (53:11) and blameless in doing no violence nor deceit (53:9). The more apt comparison lies not between the Servant and blemished animals but between the Servant and sinners who are figuratively diseased by their sinfulness. Through his identification with sinners, the Servant is ranked among them: וראת פשע'ם נמנה "And he was counted with the transgressors" (53:12). Nevertheless, the Servant also remains separate from the sinners. He makes intercession for the transgressors" (53:12), which fits the purview of a priestly role. ${ }^{60}$

\section{E CULTIC ELEMENTS CENTRED ON THE SERVANT}

This investigation of possible cultic vocabulary in Isa 53 examined relevant terms (נשא, חטא, עון ,פשע, אשם, משה , משת , imagery (a sheep led to slaughter) and allusions (scapegoat) pertaining to sacrificial ritual. The terminology in Isa 53 manifests verbal and conceptual links to cultic texts and priestly tradition, especially in Leviticus. The selected vocabulary may not be exclusive to the sacrificial system but "without considering their intertextuality with Pentateuchal ritual texts, [Isaiah 53] would simply be unintelligible in many respects." 61 Instead of being coincidental occurrences, such linguistic and conceptual parallels indicate that Isa 53 reflects a cultic context in its selection of words, concepts and imagery. It is further confirmed by the extensiveness of sacrificial elements within Isa 53, which may be grouped as follows: a type of sacrifice (אשם), a sacrificial animal (שה), hieratic activities (sprinkling, interceding and anointing), categories of sins (חשט , עון , פשע), transgressors, sacrificial ritual (the scapegoat ceremony) and procedures (leading a sheep for

58 Schipper, "Lamb Imagery," 324-325.

59 Ibid., 324.

60 Milgrom, Leviticus 1-16, 55-6: "the priest, by virtue of his sacred status, acts as the offerer's (silent) intermediary before God... he is the cultic counterpart of the prophet. Both represent the Israelites before God. Both intercede on their behalf, one through ritual, the other through prayer."

${ }^{61} \mathrm{Ha}$, "Cultic Allusions," 308. 
slaughter). Although individually the references may seem slight, their collective presence within a single passage provides strong evidence of the cultic background of Isa 53 .

Admittedly, these sacrificial references in Isa 53 are eclectic rather than a systematic development of an extended theme. For example, Isa 53 does not develop a detailed or explicit comparison between the Servant and scapegoat or set up an elaborate parallel between the Servant and a purification offering. As Hägglund has objected, "In Isa 53 we lack the priest, the ram . . . and the statement that it is an offering to YHWH." ${ }^{62}$ The lack of more explicit and fuller references in Isa 53 to the rituals discussed in Leviticus serve as a caution to some scholars against finding hints of an analogy. ${ }^{63}$ Notwithstanding, others find that the frequency and range of intertextual evidence proves the cultic context of Isa 53. Their arguments are based on the influence of a,

broadly conceived common conceptual framework believed to inform both the relevant material in Leviticus and in Isaiah 53. Thus, Mettinger refers to a 'deep structure,' Blenkinsopp refers to 'hints at' an 'analogy,' and Goldingay and Payne refer to a 'framework of thinking.' It is the cumulative effect of multiple images used to describe the servant throughout Isaiah 53 that they use to justify comparisons. ${ }^{64}$

While diverse cultic elements are evinced within Isa 53, one observes a pattern to their overall arrangement. The sacrificial elements in Isa 53 are not randomly distributed but they centre on the figure of the Servant. The roles of the Servant as priest, offering and sinner provide an effective way to locate the various cultic associations in Isa 53. The Servant is related to the priesthood through the references to his anointing (משחת 52:14), the priestly activity of sprinkling (זיה 52:15) as well as his intercession for sinners (יפגיע 53:12). Additionally, the allusions to the reparation offering (עשרם) 53:10), the sheep led for slaughter (גזר, משא (עון) 53:7) affirm the Servant's link with sacrificial offerings. Lastly, the Servant's identification with sinners is clear from the references to his bearing of others' wrongdoings (חטא עון, (חשע) and his being counted among transgressors (53:12). In sum, the Servant serves as a focal point where the roles of priest, sinner and sacrifice intersect.

This unique portrayal of a person allied with triple cultic roles suggests a correspondence between the Servant and the sanctuary. In ancient Israel, the temple was the primary site where this triad came together since sacrificial animals and other offerings were brought by the people before the priests who conducted ritual activities. As Ha remarks, "although the sanctuary is not explicitly mentioned in the [p]oem, we have here a cultic sacrificial animal, a

62 Hägglund, Isaiah 53, 69.

63 Schipper, "Lamb Imagery," 321.

64 Ibid., 320. 
cultic expiatory offering, a cultic priest, and cultic priestly activities" 65 as well as offerers /sinners, all of which concentrate on the person of the Servant. There is no comparable biblical individual in whom we find such wide-ranging sacrificial elements and multiple ritual roles combined together. Isaiah 53 clearly depicts the Servant in relation to the temple, as a locus where the priest, offering and offerer meet.

\section{F SITE OF EXPIATION}

One of the key functions of the temple is as a site of atonement where the priests offer expiatory sacrifices and the high priest conducts the "scapegoat" ritual on behalf of sinners. The parallel between the sanctuary and the Servant may be further evinced by examining the latter's expiatory role. To fully understand how the Servant functions in Isa 53, we must take into account of his suffering. He is presented as a "man of sorrows"/ איש מכאבות (53:3), enduring both physical and

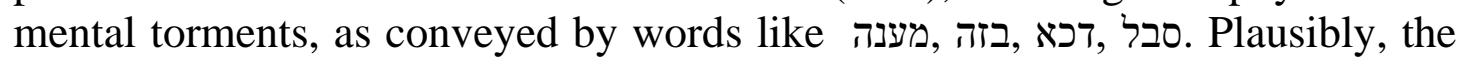
Servant's suffering resonates with the exilic experience of oppression, violence and abuse. Freyne comments,

[I]n the wake of the Babylonian captivity of the Jews and the deep religious soul-searching... Isaiah, chapter fifty-three, is the classic statement of the new and deepened understanding: the sufferings and death of the mysterious figure, the servant of God, will bear fruit and atone for the sins of the many. ${ }^{66}$

Emerging from the trauma of exile, Isa 53 accentuates three aspects of the Servant's suffering - it is vicarious, bears expiatory effects and has a cultic basis.

Firstly, the Servant's suffering may be characterised as vicarious since he endures the tribulations of others rather than his own, as evident from the phrase, מכאבינו סבלם/ "our sorrows he has borne them” (53:4). Isaiah 53 not only stresses that the Servant suffers vicariously but it also clarifies the reason for his

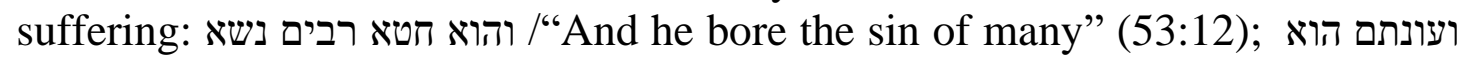
"סבל/ "And he shall bear their iniquities" (53:11) and " מפשע עמי נגע למו "for the transgressions of my people, he was stricken" (Isa 53:8). All three phrases

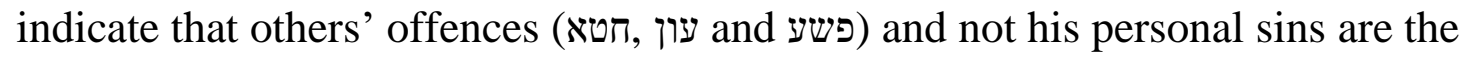
reason behind the Servant's sufferings. Although he endures the consequences of people's sinfulness, he is described as righteous and without deceit $(53: 9,11)$.

Secondly, the Servant's vicarious suffering has expiatory or redemptive effects. The phrase "ובחברתו נרפא לנו/ "By his stripes we are healed" (53:5) suggests that the Servant's ordeal results in the healing of sinners through expiation. How does one person's vicarious suffering bring about the expiation of another's sins? We may recall here the concept of נשא עון which has pertinence

65 Ha, "Cultic Allusions," 296.

66 S. Freyne, "Sacrifice for Sin,” The Furrow 25 (1974): 200. 
for the Servant's expiatory function. The term נשא עון means culpability (to bear the weight of a sin) or expiation (to bear away the weight of sin). ${ }^{67}$ The latter meaning applies best to the Servant's function in Isa 53. Although the term נשא עון does not directly occur in this pericope, as stated previously, we find variants

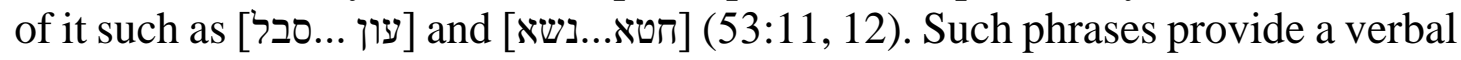
and a semantic link to Lev 16: 22, connecting the Servant with עזאזל which carries away the sins of the people. Similarly, through his vicarious suffering, the Servant bears the sins of others and in doing so removes the weight of sin from the people.

The atoning character of the Servant in Isa 53 is also bolstered by the references to אשם. Blenkinsopp remarks that the Servant's suffering and death is to be "understood as sacrificial by analogy with the ritual of the guilt or reparation offering in the book of Leviticus." 68 The Servant, like a sacrificial animal, makes reparation for the offences of others and erases their guilt.

In probing the atoning function of the Servant, the word יצדיק merits scrutiny as well. It occurs in Isa 53:11: בדעתו יצדיק צדיק עבדי לרבים "by his

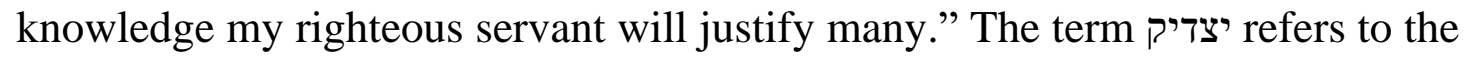
Servant making the "many" righteous. The phrase has expiatory connotations, implying that the Servant will remove people's unrighteousness by justifying them. The word יצדיק in this context "denotes the Servant's functions of judicial character as Priest but also... has a firm basis in his vicarious expiatory sacrifice as victim." 69

Thirdly, the Servant's atoning function has a cultic basis. According to Orlinsky, "nowhere in the Hebrew Bible did anyone preach a doctrine... which allowed the sacrifice of the innocent in the place of and as an acceptable substitution for the guilty."70 Notwithstanding, the sacrificial system holds precedents for the Servant's expiatory role. ${ }^{71}$ Temple animal sacrifice such as the purification and reparation offerings as well as the scapegoat ritual, resonates with the idea of vicarious suffering which expiates sins. Undoubtedly, the cultic

67 Gary Anderson, Sin: A History (New Haven: Yale University Press, 2009), 20.

68 Blenkinsopp, "Sacrificial Life," 1.

69 Ha, "Cultic Allusions," 142.

70 H.M. Orlinsky, Studies on the Second Part of the Book of Isaiah: The So-called "Servant of the Lord" and "Suffering Servant" in Second Isaiah: Isaiah 40-66 (VTSup 14; Leiden: Brill, 1977), 55.

71 An intriguing old essay by J. Philip Hyatt, "The Sources of the Suffering Servant Idea," Journal of Near Eastern Studies 3 (1944): 79-86, identifies the possible influence of "the ideas underlying the Israelite sacrificial system" on Isa 53, claiming that it "reinterprets the idea of sacrifice and views the Servant as making a sacrifice [asham] in his own person and work" but Hyatt does not link the Servant's function to that of the sanctuary in terms of ritual atonement. 
complex provides a framework within which to understand the meaning and significance of the Servant's suffering.

\section{G THE SERVANT AS SANCTUARY}

The originality of Isa 53 lies in its presenting the notion that a righteous person could vicariously suffer and atone for the sins of others on the basis of the sacrificial system. A key question worth asking is why does Isa 53 uniquely portray the Servant with cultic elements and an expiatory function only comparable to sacrificial atonement in the sanctuary? Collins states that, "the metaphorical application of the idea of sacrifice to the suffering of a human being in Isaiah 53 occurred in a context influenced by the trauma of the Babylonian exile." 72 The experience of exile which shaped Isa 53 involved a sense of guilt, angst at the loss of the temple and being cut off from God and a felt need to make reparation for past sinfulness and to reconcile with the divine. ${ }^{73}$ These anguished thoughts find expression in Lamentations which concludes with the plea, "Restore us to yourself, O LORD, that we may be restored; renew our days as of old - unless you have utterly rejected us, and are angry with us beyond measure" (5:21-23). Middlemas observes, "Just as they [understood] their God to have been the driving force behind their magnificent collapse, they view[ed] the renewal of [YHWH's] commitment as essential to the restoration of their status as the covenant people" and to receiving divine protection again. ${ }^{74}$ However, unlike in pre-exilic times when the temple had served as the central place where people's sins could be expiated by offering sacrifices, reconciling them with God, the exiles now faced the dilemma of effecting atonement without a sanctuary. In a templeless age, how could sins be atoned for a people seeking a renewed relationship with God?

Isaiah 53 addresses the problem by envisioning a person in whom the roles of priest, sinner and sacrificial offering unite and who effects expiation by suffering on behalf of others. As stated, the Servant identifies with sinners to the extent that he is counted as one of them (53:12) and suffers vicariously on their behalf (53:4). He is compared to a sacrificial animal led to slaughter (53:7) and makes reparation similar to a reparation offering $(53: 10)$. He behaves like an anointed priest, sprinkling, interceding on behalf of transgressors and justifying many (53:11-12). Through this cultic depiction of the Servant, Isa 53 offers an innovative solution to the dilemma of the templeless age. Instead of a physical place, the site and means of atonement centres on the person of the Servant. By

\footnotetext{
72 A. Yarbro Collins, "Finding Meaning in the Death of Jesus," Journal of Religion 78 (1998): 178.

73 Refer Albertz, Israel, 105: "Many were quite ready to admit their transgressions; they suffered an overwhelming burden of guilt."

74 Middlemas, Templeless, 47.
} 
envisaging a righteous sufferer who expiates for the sins of others, Isa 53 presents an alternative way to reconcile with God in the absence of a sanctuary.

Another issue that may be raised is how an individual can be compared to the temple of Jerusalem which had specific spatial, symbolic and ritual dimensions and served varied purposes. It is worth clarifying that this study does not claim that the Servant in Isa 53 represents or replaces the temple as a whole, with its multiple dimensions. Only with regard to atonement does the Servant share the same function as the sanctuary, in removing sin and restoring the relationship with the divine. As Isa 53 confirms, the "righteous servant will justify many" (53:11).

Inevitably, questions may arise about the identity of the Servant: who is this figure and how long can he perform this function? The biblical author seems to be intentionally vague about the person's identity by referring to him as a "Servant" rather than by a proper name. The text provides no concrete details about his personal background or social context to suggest that Isa 53 is referring to a specific historical figure or a biblical character. While we cannot know whether the author had an actual person in mind in delineating the Servant, the text itself manifests no clues about who the individual is and where and when his suffering take place. The pericope provides a general outline of a person who suffers and dies on behalf of others and is later exalted but whether this unnamed figure is an imagined or a real character remains unstated.

Instead of a personal description, Isa 53 develops a sacrificial portrait of the Servant, aligning him with a range of cultic elements as we have observed. Clearly, the text's emphasis is on presenting a sacrificial-expiatory perspective on the Servant. Give the exilic context in which it was likely composed, we may infer that the Servant in Isa 53 was envisaged as filling the cultic lacuna following the destruction of the temple. That a righteous, suffering Servant can effect atonement in the absence of a sanctuary was a concept which could offer hope for those who had endured the trauma of exile and the loss of the temple. While the mysteriousness of the figure has led exegetes to debate who best fits the role of the Servant, such discussions fail to consider the ingenuity of the text. As Hyatt comments, "more important than the identification of the Servant is an understanding of the boldly original idea which the prophet presents... namely, that suffering which is faithfully and willingly borne may be vicariously redemptive." "75 The innovativeness of Isa 53 lies in this notion that expiation of sins is possible even without temple ritual sacrifice.

\section{H CONCLUSION}

This study of the Servant in Isa 53 veered away from questions of identity to focus on the function of the Servant from a cultic perspective. It involved an

75 Hyatt, "The Sources of the Suffering Servant Idea," 79. 
investigation of relevant terms namely ששא , חטא, עון, פשע, יזה, משחת, We found that Isa 53 manifests substantial intertextual connections (conceptual and linguistic) to ritual texts. The pericope's wide-ranging cultic associations include references to a mode of sacrifice (אשם), a sacrificial animal (שה), priestly חטא עון (פinties (sprinkling, interceding and anointing), categories of sins פשע,), transgressors, sacrificial ritual (the scapegoat ceremony) and procedures (leading a sheep to slaughter). Furthermore, we observed that these cultic elements concentrated on the figure of the Servant. Given this intersection of the roles of priest, sacrifice and sinner/offerer, we noted a correspondence between the Servant and the sanctuary. Just as the temple served as the locus of expiation, the Servant effects atonement through his suffering, which may be defined as vicarious, expiatory and founded on a cultic basis.

In exploring why the Servant was depicted in cultic terms, we concluded that it was a creative response to the traumatic loss of the templeless age. While the exiles acknowledged their guilt and recognised their sinfulness, concurrently, their need to repent and reconcile with God became a priority. The absence of the temple resulted in creative theological ideas to restore the lost relationship with the divine, obtain forgiveness and end their alienation. Through its cultic portrayal of the Servant, Isa 53 attempts to address this problem of effecting expiation without a sanctuary.

Finally, the Servant's sacrificial associations warrant deeper inquiry. Laato claims, "the only text in the Hebrew Bible to contain the belief that the suffering and death of the righteous may become a sacrifice which is pleasing to God is Isaiah 53."76 The influence of Isa 53 on the notion of righteous sufferers who bear redemptive effects merits further research. While Christian tradition has appropriated Isa 53 in its understanding of the redemptive work of Jesus, the Servant's influence on Jewish tradition deserves further study. Specifically, the martyrdom narratives (i.e., 2 Macc 7), which share verbal and conceptual ties with Isa 53, were likely shaped by the cultic portrayal of the Servant in depicting the martyrs' own sacrificial responses in the absence of a valid cult. Baslez notes the link to Isa 53 and remarks that, "the martyr offers himself in sacrifice instead of holocausts, which are no longer celebrated.",77

Within the limited scope of this article, we examined how Isa 53 envisions the locus of atonement not as a physical sanctuary but as a person who is simultaneously priest, sacrifice and offerer and expiates for others' sins. Spieckermann suggests that "the servant is to a certain extent a 'utopian' figure

76 Antti Laato, Who Is the Servant of the Lord? Jewish and Christian Interpretations on Isaiah 53 from Antiquity to the Middle Ages (Indiana: Eisenbrauns, 2012), 63-64.

77 Marie-Francoise Baslez, "The Origin of the Martyrdom Images," in The Books of the Maccabees: History, Theology, Ideology (ed. G.G. Xeravits and J. Zsengellér; Leiden: Brill, 2006), 127. 
who must remain nameless..."78 The significance of Isa 53 rests not in the Servant's identity but in his function, revealing that reconciliation with the divine is conceivable in a templeless age.

\section{BIBLIOGRAPHY}

Albertz, R. Israel in Exile: The History and Literature of the Sixth Century B.C.E. Translation by D. Green. Atlanta: Studies in Biblical Literature, 2003.

Anderson, G.A. "Sacrifice and Sacrificial Offering." ABD 5. Edited by D. N. Freedman et al. New York: Doubleday, 1992. . Sin: A History. New Haven: Yale University Press, 2009.

Barthes, Roland. "The Theory of the Text." Pages 31-47 in Untying the Text: A Post Structuralist Reader. Edited by Robert Young. Boston: Routledge and Kegan Paul, 1981.

Baslez, Marie-Francoise. "The Origin of the Martyrdom Images." Pages 113-130 in The Books of the Maccabees: History, Theology, Ideology. Edited by G.G. Xeravits and J. Zsengellér. Leiden: Brill, 2006.

Bellinger, W.H., Jr. and William R. Farmer, eds. Jesus and the Suffering Servant: Isaiah 53 and Christian Origins. Harrisburg: Trinity Press, 1998.

Blenkinsopp, J. “The Sacrificial Life and Death of the Servant (Isaiah 52:13-53:12).” Vetus Testamentum 66 (2016): 1-14.

Childs, B.S. Isaiah. Louisville: Westminster John Knox, 2001.

Claassens, L.J.M. "Interrupting God-language: Re-thinking the Image of God as Liberator in Isaiah 42." Pages 53-70 in Exile and Suffering: A Selection of Papers Read at the 50th Anniversary Meeting of the Old Testament Society of South Africa. OTWSA/OTSSA Pretoria, August 2007. Edited by B. Becking and D. Human. Leiden: Brill, 2009.

Driver, S.R. and A. D. Neubauer, eds. The Fifty-third Chapter of Isaiah: According to the Jewish Interpreters. Oxford: James Parker and Co., 1877. Repr. 2005.

Ehrman, B.D. The Bible: A Historical and Literary Introduction. New York: Oxford, 2014)

Freyne, S. "Sacrifice for Sin." The Furrow 25 (1974): 193-212.

Garber, D.G. "Trauma Theory and Biblical Studies." Currents in Biblical Research 14 (2015): $24-44$.

Gentry, Peter J. "The Atonement in Isaiah's Fourth Servant Song (Isaiah 52:1353:12)." The Southern Baptist Journal of Theology 11(2007):20-47.

Greer, J.S. "The 'Priestly Portion' in the Hebrew Bible: Its Ancient Near Eastern Context and Its Implications for the Composition of P." Journal of Biblical Literature 138 (2019): 263-284.

Ha, Kyesang. "Cultic Allusions in the Suffering Servant Poem (Isaiah 52:13-53:12)." Ph.D Thesis. Andrews University, 2009: http://digitalcommons.andrews.edu/dissertations.

Hägglund, Fredrik. Isaiah 53 in the Light of Homecoming after Exile. Tübingen: Mohr Siebeck, 2008.

Hays, Richard. Echoes of Scripture in the Letters of Paul. New Haven: Yale University, 1989.

78 Spieckermann, "Conception," 14. 
Hermisson, Hans-Jürgen. "The Fourth Servant Song in the Context of Isaiah.” Pages 16-47 in The Suffering Servant: Isaiah 53 in Jewish and Christian Sources. Edited by B. Janowski and P. Stuhlmacher. Grand Rapids: Wm B. Eerdmans, 2004.

Hyatt, Philip. "The Sources of the Suffering Servant Idea." Journal of Near Eastern Studies 3 (1944): 79-86.

Janowski, B. "He Bore Our Sins: Isaiah 53 and the Drama of Taking Another's Place." Pages 48-74 in The Suffering Servant: Isaiah 53 in Jewish and Christian Sources. Edited by B. Janowski and P. Stuhlmacher. Grand Rapids: Eerdmans, 2004.

Janowski, Bernd and Peter Stuhlmacher, eds. The Suffering Servant: Isaiah 53 in Jewish and Christian Sources. Grand Rapids: Wm B. Eerdmans, 2004.

Kristeva, Julia. The Kristeva Reader. Edited by Toril Moi. New York: Columbia UP, 1986.

Laato, Antti. Who Is the Servant of the Lord? Jewish and Christian Interpretations on Isaiah 53 from Antiquity to the Middle Ages. Indiana: Eisenbrauns, 2012.

Lapin, Hayim and Marjorie Lehman. "Introduction to the Theme: The Jerusalem Temple in History, Memory, and Ritual." AJS Review 43 (2019): 265-269.

Meek, Russell L. "Intertextuality, Inner-biblical Exegesis, and Inner-biblical Allusion: The Ethics of a Methodology." Biblica 95 (2014): 280-291.

Middlemas, Jill. The Templeless Age: An Introduction to the History, Literature, and Theology of the "Exile." Louisville: Westminster John Knox Press, 2007.

Milgrom, J. Cult and Conscience: The Asham and the Priestly Doctrine of Repentance. Studies in Judaism in Late Antiquity 18. Leiden: Brill, 1976.

.Leviticus 1-16: A New Translation with Introduction and Commentary. AB 3. New York: Doubleday, 1991.

Miller, G. "Intertextuality in Old Testament Research." Currents in Biblical Research 9 (2010): 283-309.

Moyise, Steve. "Intertextuality and Biblical Studies: A Review." Verbum et Ecclesia 23 (2002): 418-431.

Orlinsky, H.M. Studies on the Second Part of the Book of Isaiah: The So-called "Servant of the Lord" and "Suffering Servant" in Second Isaiah: Isaiah 40-66. VTSup 14. Leiden: Brill, 1977.

Rembaum, Joel E. "The Development of a Jewish Exegetical Tradition Regarding Isaiah 53." Harvard Theological Review 75 (1982): 289-311.

Schipper, Jeremy. Disability and Isaiah's Suffering Servant. Oxford: Oxford University Press, 2011.

"Interpreting the Lamb Imagery in Isaiah 53." Journal of Biblical Literature 132 (2013): 315-325.

Spieckermann, Hermann. "The Conception and Prehistory of the Idea of Vicarious Suffering in the Old Testament." Pages 1-15 in The Suffering Servant: Isaiah 53 in Jewish and Christian Sources. Edited by B. Janowski and P. Stuhlmacher. Grand Rapids: Wm B. Eerdmans, 2004.

Story, Cullen. "Another Look at the Fourth Servant Song of Second Isaiah." Horizons in Biblical Theology (2009): 100-110.

Yarbro Collins, A. "Finding Meaning in the Death of Jesus." Journal of Religion 78 (1998): 175-196. 
Zimmerli, W. "Zur Vorgeschichte von Jes. 53.” Pages 236-244 in Congress Volume, Rome, 1968. Edited by G.W. Anderson et al. VTSup 17. Leiden: Brill, 1969.

Dr. Paba Nidhani De Andrado, Assistant Professor, Dept of Theological Studies, St Louis University, St. Louis, MO 63108-3414, USA. E-mail: pdeandrado@yahoo.com ORCID ID: https://orcid.org/0000-0003-0591-8980. 